University of Nebraska - Lincoln DigitalCommons@University of Nebraska - Lincoln

US Fish \& Wildlife Publications

US Fish \& Wildlife Service

2-3-2005

UNITED STATES DISTRICT COURT FOR
THE DISTRICT OF COLUMBIA

Follow this and additional works at: http://digitalcommons.unl.edu/usfwspubs

"UNITED STATES DISTRICT COURT FOR THE DISTRICT OF COLUMBIA" (2005). US Fish ఓ Wildlife Publications. 448.

http://digitalcommons.unl.edu/usfwspubs/448

This Article is brought to you for free and open access by the US Fish \& Wildlife Service at DigitalCommons@University of Nebraska - Lincoln. It has been accepted for inclusion in US Fish \& Wildlife Publications by an authorized administrator of DigitalCommons@University of Nebraska - Lincoln. 


\section{UNITED STATES DISTRICT COURT \\ FOR THE DISTRICT OF COLUMBIA}

\begin{tabular}{ll}
\hline GOVERNMENT OF THE PROVINCE & ) \\
OF MANITOBA, & ) \\
Plaintiff, & ) \\
v. & ) \\
GALE A. NORTON, Secretary, United & ) \\
Stated Department of the Interior, et al., & ) \\
& ( ) \\
Defendants. & )
\end{tabular}

Civil Action No. 02-cv-02057 (RMC)

\section{MEMORANDUM OPINION}

The United States Government and the State of North Dakota have begun construction on a project that is designed to transfer water through a mountain range from the Missouri River Basin into the Hudson Bay Basin for purposes of providing water to numerous small communities in North Dakota. This "NorthWest Area Water Supply Project" ("NAWS") would be the first federally-sponsored interbasin transfer of water.

The Province of Manitoba, Canada ("Manitoba") has filed suit against Gail A. Norton, Secretary of the Department of the Interior, John W. Keys, III, Commissioner of the Bureau of Reclamation, Maryanne C. Bach, Great Plains Regional Director of the Bureau of Reclamation, and Dennis E. Breitzman, Dakotas Area Manager of the Bureau of Reclamation (collectively, “Federal Defendants"). Manitoba challenges the Federal Defendants' compliance with the National Environmental Policy Act of 1969, 42 U.S.C. $§ 4321$, et seq. ("NEPA"), in connection with their consideration and approval of the water transfer project. More particularly, Plaintiff contends that the April 30, 2001 Environmental Assessment ("EA") for the project is inadequate and that the 
Finding of No Significant Impact (“FONSI"), dated May 18, 2001, as revised September 10, 2001, together with the actions based thereon, are therefore arbitrary, capricious, an abuse of discretion, and otherwise not in accordance with law within the meaning of Section 10 of the Administrative Procedure Act, 5 U.S.C. $\S 706(2)(A)$. The point of contention is the degree to which NAWS threatens to bring non-native biota from the Missouri River Basin into the Hudson Bay Basin.

Pending before the Court are Cross-Motions for Summary Judgment filed by Manitoba, Federal Defendants, and Intervenor-Defendant, the State of North Dakota ("North Dakota"). Manitoba's motion is supported by amici curiae the Government of Canada and the State of Missouri. Upon consideration of the arguments presented in the parties' memoranda and at oral argument, the Court will grant in part, and deny in part, Manitoba's motion for summary judgment and will deny the motions of Federal Defendants and North Dakota.

\section{BACKGROUND}

The Continental Divide separates water flows in the Unites States so that streams flow to opposite sides of the continent. Where it goes through North Dakota, the divide separates two river basins, the Missouri River Basin and the Hudson Bay Basin. AR at 862. ${ }^{1}$ On the western side of the divide in North Dakota, the Missouri River flows into the Missouri River Basin and eventually drains south to the Gulf of Mexico. On the eastern side of the divide, the waters flow north and east into the Hudson Bay Basin. AR at 545.

These basins have distinct ecological characteristics and contain different species of fish and other aquatic organisms, as well as pathogenic species such as bacteria, viruses, protozoa,

1 Within the Hudson Bay Basin are the watersheds of Lake of the Woods, the Red and Souris Rivers, Lake Manitoba, and Lake Winnipeg. AR at 864. The basin's principal watercourses are the Saskatchewan and Winnipeg rivers. AR at 862. 
fungi, and other microscopic organisms. AR at 1200; Pltf's Motion for Summary Judgment at $4 .^{2}$ The co-mingling of untreated water from one basin into another can result in the introduction of biota -- the various life forms of a particular region or habitat -- that may be invasive and dangerous to indigenous biota. ${ }^{3}$ The effect upon fish of "interbasin biota transfer," for example, can be devastating. The introduction of foreign biota can eliminate indigenous species, cause reduced growth and survival rates in indigenous species, and change the trophic structure of fish communities. AR at 3005. In documented cases, non-native species have displaced native species through direct competition, predation, inhibition of reproduction, environmental modification, transfer of new parasites and diseases, and destruction of the gene pool through hybridization. AR at $3005 .^{4}$

2 There are a number of fish species that exist in the Missouri River that are not found in the Hudson Bay Basin. "These species include the pallid sturgeon, paddlefish, shovelnose sturgeon, shortnose gar, gizzard shad, Utah chub, smallmouth buffalo, and river carpsucker." AR at 9816 (citations to report omitted).

$3[\mathrm{I}]$ nterbasin biota transfer is the transfer, through man-made structures, as well as through nature processes, of life forms from one watershed drainage basin to another. Transferred life forms of concern can include viruses, bacteria, protozoans and other invertebrates, fish, fish eggs and other aquatic organisms, as well $\mathrm{AR}$ at 544. as macrophytic plants and algae.

$4 \quad$ Introduction of different species from one basin to another can result in replacement of native or other desirable species with less desirable ones. Transfer of infected fish, protozoans, parasites, viruses, and bacteria can also result in fish diseases and epizootics to native flora or fauna with long-term implications. There are many documented cases of interbasin biota transfer; the most recently well publicized situation is the introduction of zebra mussel into the Great Lakes and other regions of North America from Europe.

$\mathrm{AR}$ at 544. 
Aquatic invasive or non-indigenous species are organisms that have moved beyond their natural geographical ecosystem. They may include fish, fish pathogens and parasites, invertebrates, and aquatic plants. When a new species or organism is introduced into an ecosystem, the economic and ecological consequences can be detrimental and irreversible.

Aquatic non-indigenous species can cause complex changes within their new environment as evidenced by the zebra mussel and many other species .... Changes to aquatic ecosystems can include a decline in the abundance of native species, extirpation of rare or endangered species, introduction of new diseases to native populations, alteration of the gene pool of native species, and reductions in reproductive success, genetic integrity, and biodiversity.

AR at 9815-17 (internal citations to reports omitted).

The transfer of biota can occur in many different ways, both natural and unnatural. "Direct connection through water is only one of several possible ways for biota to be transferred between basins. Many vectors, or pathways, have been identified including attachment to birds, insects, through fish-stocking programs, transfer of biota in live wells and bilge water of recreational or commercial water craft, and through live bait transport." AR at 544. Flooding and other natural events can also transfer biota from basin to basin.

\section{NorthWest Area Water Supply Project}

For many years, northwestern North Dakota has experienced water supply problems.

AR at 466. Many municipalities and small communities in the region, as well as farms and ranches, rely upon groundwater sources that are finite or of poor quality. AR at 466. The largest city in the region, Minot, North Dakota, currently obtains most of its water from the Minot and Sundre aquifers. $\mathrm{AR}$ at 470. In the past, these aquifers were recharged by water from the Souris River. However, increased water usage and the construction of two water storage reservoirs in Canada -- which 
reduced flows on the Souris River in the United States -- have limited the amount of available water in these aquifers. AR at 470. See AR at 498 (The Souris River flows south from Canada into North Dakota, takes a wide swing through the northwest part of the state, and flows north back into Canada.).

The NorthWest Area Water Supply Project is a joint federal-state project that "involves the construction of a municipal, rural, and industrial [] bulk water distribution system in North Dakota." Compl. I 2. The Bureau of Reclamation ("Bureau" or "BOR"), through the Secretary of the Interior, is charged with planning and construction and is accomplishing this with the State of North Dakota. The primary purpose of this project is to provide drinking water that meets the "secondary" standards of the Safe Water Drinking Act, 42 U.S.C. § 300f, to local communities and rural water systems in eight to ten counties in North Dakota. AR at 470-71.

The cornerstone of the project is the source of the water for NAWS. As presently contemplated, NAWS would withdraw over three and one-half billion gallons of Missouri River water from Lake Audubon or Lake Sakakawea every year. The water, which would be partially disinfected and pre-treated south of the basin divide, would flow through buried pipelines across the divide into the Hudson Bay Basin where it would receive final treatment in Minot, North Dakota prior to distribution. ${ }^{5}$ The finished water would be delivered by pipeline to communities and rural water systems north of the basin divide. Water from the project would drain into the Souris River, which flows into Manitoba. Upon completion, NAWS would establish the first artificial link in 10,000 years between the Missouri River Basin and the Hudson River Basin.

5 See AR at 545 ("The NAWS pipeline, from the intake structure of the Missouri River basin to the Minot water treatment plant . . . crosses the divide between the Missouri River basin and the Hudson Bay basin ...."). 
From the outset, the potential of NAWS to transfer Missouri River Basin biota to the Hudson Bay Basin has been recognized as a major concern, prompting considerable study, analysis, and diplomatic negotiation among interested parties. AR at 823 ("Since 1981, numerous international committees and groups have been formed to address this issue at both a policy and technical level."); see, e.g., AR at 1023 (1990 Garrison Joint Technical Committee, Biology Task Force Report); AR at 1199 (1994 NAWS Engineering-Biology Task Group). The parties to this litigation agree that such a transfer could have catastrophic consequences. "One of the greatest concerns for irreversible commitments of resources is interbasin biota transfer. Most often, when this occurs, the damage is not reversible.” AR at 591; see AR at 1201, Engineering-Biology Task Group Report ("The effects of the introduction of a disease pathogen or parasite could be catastrophic to wild or cultured fish.”).

In 1994, the NAWS Chloramine Challenge Study was undertaken to investigate the effectiveness of chloramination and ozonation for disinfection and pre-treatment of Missouri River water. The study developed "experimental protocols for microbial inactivation using chlorine/chloramine and ozone. The chlorine/chloramine protocols included both Giardia and MS2 Bacteriophage inactivation experiments." AR at 825. The ozone protocols were also developed for Giardia inactivation. The results of the study indicated that both chloramine and ozone "could be employed for disinfection of Lake Audubon water." AR at 825-26.

Early studies concluded that the "risk of biota transfer from NAWS was 'low' but did not quantify this determination." AR at 1863. In 2000, the Bureau prepared a Comparative Risk Assessment ("CRA"), which was designed to "quantitatively analyze potential risks and to present 
a mathematical and statistical basis to better define a 'low risk." AR at $1863 .{ }^{6}$ Notably, the CRA used the organism, Giardia, as a surrogate for species presumed to be non-native biota. In addition, Whirling Disease ("WD"), a parasitic protozoan, was used as representative of disinfection resistant organisms. AR at 1863 ("The CRA addressed the microorganisms Giardia, viruses, and [WD] spores only."). The study concluded that "[f]rom the time water is withdrawn from [the intake in the Missouri River Basin] until the used water is discharged from wastewater plants to the Souris River by users, about 99.9999999 percent of Giardia and 99.9999999999999 percent of viruses are likely to be inactivated or removed from the water." AR at 1864 .

Later, in August 2001, the Plaintiff commissioned a "Technical Report" ("TetrES Report") that showed that "because of significant new findings after 1994 regarding disinfection efficacy for protozoans such as Cryptosporidium ... the conclusions of [earlier studies] are outdated and are no longer relevant for a project proposed for construction over seven years later." AR at 9831. This study further suggested that reliance upon Giardia, virus, and WD as representative organisms by which to assess the effectiveness of treatment using chloramine was misplaced because, inter alia, those organisms are highly treatable or innocuous if introduced into a foreign

${ }^{6}$ The CRA was commissioned to determine whether "the NAWS project would comply with the Boundary Waters Treaty" in light of Canadian concerns "that the transfer of water .. . could result in transfer of non-native biota to Canadian waters." AR at 1863.

${ }^{7}$ Federal Defendants argue that the Court should not consider this report because it was submitted at the "Eleventh Hour." Fed. Defs' Reply at 2. While a court reviewing an agency decision is normally confined to the administrative record compiled by that agency when it made its decision, deviation from this "record rule" is common in NEPA cases. See Nat'l Audubon Soc'y v. Hoffman, 132 F.3d 7, 14-15 (2d Cir. 1997). Such extra-record review can be critical to the judicial inquiry regarding the completeness of the agency record. Because the TetrES Report will assist the Court in determining whether the agency engaged in a supportable assessment of environmental effects of NAWS, strict adherence to the "record rule" is not required. 
system. In sum, the TetrES Report concluded that analysis using "treatment resistant organisms like Cryptosporidius," would better present the true effectiveness of such pre-treatment. AR at 9832.

\section{Administrative Proceedings}

Due in large measure to concerns over the interbasin transfer of biota, NAWS has a long and torturous history of project development in which numerous alternative water supply systems have been analyzed and considered. AR at 472 . Several parameters were considered in assessing alternatives, including the quantity and quality of the water source, limits of service areas, type of treatment, intake facilities, adaptability to phased construction, environmental impacts, capital costs, and operation and maintenance costs. AR at 478. From 1988 to 1993, the number of alternatives was reduced from ten to three.

In June 1997, the Bureau released a draft EA for NAWS. The initial work on the EA evaluated three alternatives. See AR at 1361- 1411, February 27, 1997 Environmental Assessment Alternative Analysis (identifying Alternative A - an integrated system; Alternative B - an individual treatment system; Alternative $\mathrm{C}-\mathrm{a}$ combination of Alternatives A \& B). Public meetings on the Draft EA were held, and interested parties including Canada and the Environmental Protection Agency ("EPA") submitted written comments. The Bureau subsequently issued a Final EA on April 30,2001 , concluding that "[t]he risk of interbasin transfer of non-native biota as a result of the NAWS project is considered low." Compl. $\mid 46$. The Final EA analyzed three alternatives and a noaction alternative. AR at 478 .

Alternative A included an intake of Missouri River water at either Lake Audubon or Lake Sakakawea, a pre-treatment facility at the intake or at a booster pump station, and upgrade of the water treatment plant ("WTP") in Minot. AR at 479. The pipeline between intake at the lakes 
and the Minot WTP would be about forty-five miles long and include pumping stations and storage reservoirs. AR at 479-80. The Missouri River water would be disinfected with ozone or chlorine/chloramine -- with a chloramine residual maintained in the pipeline for biofilm control -at a pre-treatment facility on the Missouri River Basin side of the divide to provide biota transfer control and inactivation of protozoan pathogens and viruses. AR at 479-81. After reaching the Minot WTP, the pre-treated water would be disinfected further with ultraviolet radiation before being delivered to communities and the rural water systems by way of 413 miles of distribution pipeline.

Unlike Alternative A, Alternative B would not have used Missouri River water at all, relying upon the existing water sources of users. AR at 485. This alternative would have required the drilling of additional wells, some additional pipelines, and other upgrades, but would have eliminated the need for 407 miles of pipeline compared to Alternative A, and 298 miles of pipeline as compared to the Preferred Alternative. AR at 489. It would not have involved the interbasin transfer of Missouri River water.

The Preferred Alternative combined Alternatives A and B and was developed "based on the capital costs for both an integrated system and individual treatment systems.” AR at 495.

The Preferred Alternative would have one intake at either Lake Sakakawea or Lake Audubon, a pre-treatment facility at the intake or the Max booster pump station, one central treatment plant at Minot, eight storage reservoirs, 13 pumping plants, 304 miles of distribution pipelines, two new treatment plants with drain ponds (Wildrose and Grenora), and one upgraded treatment plant (Parshall).

$\mathrm{AR}$ at 495.

Under Alternative A and the Preferred Alternative, Missouri River water would be 
pumped from either Lake Sakakawea or Lake Audubon. AR at 499. Also under both alternatives, the Missouri River water would first be pre-treated at or near the intake and later treated to "drinking water" standards at the Minot WTP. The Final EA pointed out that "[t]wo options were analyzed and eliminated for the treatment of Missouri River water to reduce the possibility of interbasin biota transfer into the Hudson Bay watershed:" full treatment at Minot and full treatment at the intake. AR at 508. Full treatment at the Minot WTP involved a cost of $\$ 15.9$ million, but "was dropped because of unacceptable risk of interbasin biota transfer." AR at 508. Full treatment at the intake "would have required the construction of a complete, new treatment plant," and would have cost \$28.2 million. AR at 508-09. "The difference in cost between a full treatment plant at Lakes Audubon or Sakakawea and upgrade of the Minot treatment plant is $\$ 12.3$ million ( $\$ 28.2$ million \$15.9 million).” AR at 509 (internal cross-reference omitted). Accordingly, both alternatives using water drawn from the Missouri River called for pre-treatment at the intake and at the Minot water treatment plant because it "was considered the most viable and most supportable treatment alternative in terms of costs, financing, and use of existing facilities." AR at 510.

Based on the findings in the Final EA, the Bureau issued a FONSI on May 18, 2001, which stated that a full Environmental Impact Study (“EIS") was not necessary for NAWS because "[r]easonably foreseeable activities, as described in the EA, will not have adverse effects on the human or natural environment." Compl. $\uparrow 47 .^{8}$ Following an administrative appeal by Manitoba

8 The reasons for the FONSI determination were summarized as follows:

1) All potential environmental issues have been identified and analyzed for impacts to the human and natural environment. Any negative impacts will be mitigated by the environmental commitments identified in this FONSI. 
Conservation (the provincial agency of Manitoba), Environment Canada (the federal Canadian environmental agency), and a North Dakota citizen, Dr. Gary Pearson, in which the TetrES Report was presented, on September 10, 2001, the Bureau issued a revised FONSI and a decision upholding the determination that an EIS was not necessary. The revised FONSI noted that the "issue of full treatment versus pretreatment at the intake site is a difficult, but critical one.” AR at 752 .

Technical studies have been conducted to find a solution that is responsible and reasonable from both an economic and environmental standpoint. Pretreatment using both ozone and chloramine, as proposed in the Preferred Alternative, will meet requirements set by the Garrison U.S./Canada Consultative Group for prevention of biota transfer. The Northwest Area Water Supply Project Chloramine Challenge Study - December 1995 demonstrated that pretreatment with either chloramine or ozone provides disinfection of Giardia to 3-log detection (inactivation) and Bacteriophage to 4-log detection (inactivation) ..... We believe the incremental reduction in the environmental risk of biota transfer provided by full treatment at the intake, compared to that of pretreatment, does not warrant the additional cost of constructing full treatment facilities at the source.

AR at 752-53.

2) No threatened or endangered species will be adversely affected ...;

3) All stipulations of the National Historic Preservation Act ... have been incorporated;

4) The project area does not contain Indian Trust Assets ... ;

5) All applicable Federal and State environmental laws, regulations, and executive orders will be adhered to; and

6) The Secretary of the Interior, in consultation with the U.S.

Environmental Protection Agency and the U.S. Department of State, has determined that the project will not violate the Boundary Waters Treaty of 1909 .

AR at 0676 . 


\section{Construction Underway}

Construction on NAWS, which is estimated to take five years, began in 2002 and, as of April 13, 2004, 16.5 miles of the core pipeline (38 percent) had been constructed. The entire cost of the project is estimated at $\$ 145$ million, with 65 percent of that cost provided by the federal government. Three contracts have been awarded for NAWS at a total cost of $\$ 16.6$ million. In addition to the pipeline, the project requires construction of storage reservoirs, two new WTPs, an upgraded retreatment plant, and pumping plants. AR at 495. All told, the project will serve about 81,000 people. AR at 473. Water likely will not flow into Minot until at least 2008. Bach Decl. ๆ 4.

\section{ARGUMENTS}

Manitoba challenges the Federal Defendants' compliance with NEPA in connection with their consideration and approval of NAWS. Plaintiff's principal argument is that the Bureau, in reaching its determination that no EIS was required, considered outdated 1994 EPA standards of disinfection and treatment. Pltf's Motion for Summary Judgment at 5. Manitoba argues that EPA has revised its standards since 1994 "to require control of the more treatment-resistant organism Cryptosporidium, as well as Giardia, and substantial improvements have been made in disinfection technology" and that, in any event, the "Bureau must examine the real world, not the world as governed by standards that are long out of date" in considering the environmental impact of its actions. Id. at 5-6. Plaintiff claims that "[t]he Bureau rejected, without fully analyzing, complete treatment of Missouri River water at the source," id. at 6, and that there is "substantial uncertainty about the effectiveness of the Bureau's control measures," $i d$. at 9. In light of these substantial uncertainties and the potential for interbasin transfer of biota through "catastrophic system failures," 
"normal and expected leakage from line joints and connectors," "and discharges to the environment of backwash water and residue or sludge from treatment processes in Minot," Manitoba contends that a finding of no significant impact is unsupportable. $I d .^{9}$

Federal Defendants' arguments proceed on the assumption that the pretreatment process results in a low risk of biota transfer. In what is a constant drumbeat throughout the briefing, they argue that the project will result in a disinfection rate that "is greater than $99 \%$ for biota of concern to the Province - meeting the goal agreed to by the international commission reviewing the project." Fed. Defs' Opp. and Motion for Summary Judgment at $1 .{ }^{10}$

This pre-treatment will 'meet the disinfection requirement of 3-log and 4-log inactivation of Giardia and viruses, respectively.' This means that DOI anticipates a disinfection success rate of $99.9 \%$ and $99.99 \%$ approximately thirteen miles before the flow in the pipeline reaches the basin divide. By the time the water reaches the divide, DOI expects an additional 2 logs of inactivation for Giardia and an additional 4 logs for viruses, resulting in a disinfection rate of $99.999 \%$ and $99.999999 \%$.

Id. at 15. Federal Defendants acknowledge that Cryptosporidium is more treatment-resistant than

${ }^{9}$ Manitoba contends that NAWS threatens to irreparably harm it by introducing alien and invasive species in the Hudson Bay Basin that "would pose serious threats to the aquatic resources which are owned and managed by the Province." Pltf's Motion for Summary Judgment at 18. "If water from the Missouri River is permitted to flow across the basin divide, non-native biota are likely to be introduced into the Hudson Bay Basin, either by accident or routine release ... [e]specially in the case of ongoing and predictable leakage, which will be impossible to prevent at all times and places along the pipeline ...."Id.

${ }^{10}$ Federal Defendants assert that the complaint raises a non-justiciable political question because "the discussion of the biota transfer issue in the EA is part and parcel of the same determination made as part of the United States' compliance with its [Boundary Water] Treaty obligations." Fed. Defs' Opp. and Motion for Summary Judgment at 41. They contend that Manitoba is "indirectly challenging compliance with the Treaty under the guise of a NEPA claim." Id. at 42. The fact that construction of NAWS involves political concerns or consideration of treaty obligations is not relevant to the NEPA inquiry and is not grounds for dismissal. 
Giardia but assert that there are no laboratory procedures to evaluate Cryptosporidium. They contend that the use of older EPA standards is justified because there are no relevant standards relating directly to control of biota transfer. In any event, Federal Defendants argue that after treatment with ultra-violet ("UV") light at the Minot WTP, 99.9 to 99.99\% deactivation of organisms such as Cryptosporidium should result. Id. at 19.

They counter Manitoba's suggestion that the Department of the Interior ("DOI") did not consider full treatment at the intake (to include Cryptosporidium-specific treatment), arguing that this alternative was eliminated from further review because it would have "required the construction of a 'complete and new treatment plant' . . resulting in significant increase in cost, the closure of the Minot treatment plant" and other difficulties. Id. at 30. These considerations and "the very low risk of biota transfer associated with pre-treatment at the source and final treatment at Minot combined to support DOI's approach." Id. at 31 .

Intervenor-Defendant North Dakota ("North Dakota") argues that mitigation efforts, in particular pipeline engineering features, will minimize the possibility of leaks and interbasin biota transfer. North Dakota's Opp. and Motion for Summary Judgment at 22. North Dakota noted further that the difference in treatment effectiveness between full treatment at the source and the Preferred Alternative was "literally one hundredth of a percent, at most . . at a cost of at least \$27 million in front-end costs for the project." Id. at 34 .

\section{NATIONAL ENVIRONMENTAL POLICY ACT}

In 1969, Congress passed NEPA to ensure that agencies of the federal government consider the environmental effects of proposed actions. NEPA was enacted "[t]o declare a national policy which will encourage productive and enjoyable harmony between man and his environment; 
to promote efforts which will prevent or eliminate damage to the environment and biosphere and stimulate the health and welfare of man; to enrich the understanding of the ecological systems and natural resources important to the Nation; and to establish a Council on Environmental Quality." 42 U.S.C. $\S 4321$.

The Act was designed to "promote environmentally sensitive decision-making without prescribing any substantive standards," Anderson v. Evans, 314 F.3d 1006, 1016 (9th Cir. 2002), and "guarantees that the relevant information will be made available to the larger audience that may also play a role in both the decisionmaking process and the implementation of that decision." Robertson v. Methow Valley Citizens Council, 490 U.S. 332, 349 (1989). This audience includes the public, as well as "the President, who is responsible for the agency's policy, and Congress, which has authorized the agency's actions." Sierra Club v. Watkins, 808 F. Supp. 852, 858 (D.D.C. 1991) (citing Nat'l Res. Def. Council, Inc. v. Morton, 458 F.2d 827, 833 (D.C. Cir. 1972)); see Grand Council of the Crees v. FERC, 198 F.3d 950, 959 (D.C. Cir. 2000) (congressional purpose to ensure agency access to detailed environmental impact information and to inform the public of environmental concerns). Such information is critical for decision-makers who must “decide whether they will support or overrule the agency's action . . ." Watkins, 808 F. Supp. at 858; see Monroe County Conservation Council, Inc. v. Volpe, 472 F.2d 693, 697 (2d Cir. 1972) (NEPA requires full disclosure for decision-makers and the public).

The heart of NEPA is its "action-forcing" procedures, which ensure that broad policy concerns regarding environmental quality are infused into the actions of the federal government. Robertson, 490 U.S. at 349 (citing 115 Cong. REC. 40416 (Dec. 20, 1969) (remarks of Sen. 
Jackson); S. REP. No. 91-296, at 19 (1969)). ${ }^{11}$ The most important of these procedures is the requirement that an EIS be prepared whenever a proposed major federal action will significantly affect the quality of the human environment. Sierra Club v. Peterson, 717 F.2d 1409, 1413 (D.C. Cir. 1983). This cornerstone of NEPA requires that federal agencies:

(C) include in every recommendation or report on proposals for legislation and other major Federal actions significantly affecting the quality of the human environment, a detailed statement by the responsible official on -

(i) the environmental impact of the proposed action,

(ii) any adverse environmental effects which cannot be avoided should the proposal be implemented, (iii) alternatives to the proposed action, (iv) the relationship between local short-term uses of man's environment and the maintenance and enhancement of long-term productivity, and

(v) any irreversible and irretrievable commitments of resources which would be involved in the proposed action should it be implemented.

42 U.S.C. $\S 4332(2)(C)$ (emphasis added).

"Whether a particular proposed action significantly affects the environment, thus necessitating the preparation of an EIS, is a threshold question." Nat'l Audubon Society v. Hoffman, 132 F.3d 7, 12 (2d Cir. 1997). "[I]f the agency is uncertain whether the impacts rise to the level of a major federal action requiring an EIS, the agency must prepare an [EA].” Id. at 13 (citing 40 C.F.R. $\S \S 1501.3,1501.4,1508.9$ ); see also Peterson, 717 F.2d at 1413 (citing 40 C.F.R. $§ 1501.4(b)$ \& (c)). An EA is a concise public document that "[b]riefly provide[s] sufficient evidence and analysis for determining whether to prepare an [EIS] or a [FONSI]." 40 C.F.R. $\S 1508.9$. If the agency finds that the proposed action will produce "no significant impact" on the environment, then an EIS is not required. 40 C.F.R. § 1501.4(e); see Sierra Club v. Espy, 38 F.3d 792, 296 (5th Cir.

11 NEPA acts as "an environmental overlay on the statutory responsibilities of all federal agencies.” Daniel R. MAndelker, NEPA LAw ANd Litigation $§ 1.1$ (2d ed. 2004). 
1994) (if there is a finding of no significant impact an EIS is not required). A FONSI is an agency document that "briefly present[s] the reasons why an action ... will not have a significant effect on the human environment and for which an environmental impact statement therefore will not be prepared.” 40 C.F.R. $§ 1508.13$.

\section{STANDARD OF REVIEW}

By their design, these "action-forcing" requirements are "almost certain to affect the agency's substantive decision, [but] it is now well settled that NEPA itself does not mandate particular results ...." Robertson, 490 U.S. at 350; see Vermont Yankee Nuclear Power Corp. v. NRDC, 435 U.S. 519, 558 (1978) (describing the requirements of NEPA as “essentially procedural”); Stryker's Bay Neighborhood Council, Inc. v. Karlen, 444 U.S. 223, 227 (1980) (rejecting claim that NEPA demands that an agency elevate environmental concerns over other considerations); North Slope Borough v. Andrus, 642 F.2d 589, 599 (D.C. Cir. 1980) (NEPA requirements are essentially procedural and a court should not substitute its own policy judgment for that of the agency). "NEPA merely prohibits uninformed -- rather than unwise -- agency action." Robertson, 490 U.S. at 351. Compliance with the procedural requirements themselves, however, is not discretionary and a court may review the decision to forego production of an EIS. Kleppe v. Sierra Club, 427 U.S. 390, 420 (1976); see Hoffman, 132 F.3d at 18 (“[B]ecause NEPA provides a procedural framework ... courts are responsible for ensuring that agencies comply with the statutory duty imposed on them by Congress."). Judicial review of an agency FONSI and decision not to complete an EIS is performed according to the Administrative Procedure Act, 5 U.S.C. $\S 706(2)(A)$. Dep't of Transp. v. Public Citizen, 124 S. Ct. 2204, 2213 (2004). An agency has broad discretion in making such determinations and the decision is reviewable only if it was arbitrary, capricious, or 
an abuse of discretion. Sierra Club v. United States Dep't of Transp., 753 F.2d 120, 126 (D.C. Cir. 1985) (citing Cabinet Mountains Wilderness / Scotchman's Peak Grizzly Bears v. Peterson, 685 F.2d 678, 681 (D.C. Cir. 1982)). While deferential, a court must thoroughly review an agency's decision and may not "rubber stamp" decisions that are inconsistent with statutory mandate or congressional policy. Ariz. Cattle Growers Ass'n v. United States Fish \& Wildlife Serv., 273 F.3d 1229, 1236 (9th Cir. 2001).

ANALYSIS

The first threshold question is whether the interbasin transport of Missouri River water, with the possible transfer of non-indigenous biota to the Hudson Bay Basin, is a "[m]ajor Federal action.” 42 U.S.C. 4332(2)(C); see Mineral Policy Ctr. v. Norton, 292 F. Supp. 2d 30, 53 (D.D.C. 2003) (citing Fund for Animals v. Thomas, 127 F.3d 80, 83 (D.C. Cir. 1997)) (duty to prepare an EIS triggered only by a proposal for major Federal action). Regulations promulgated by the Council on Environmental Quality ("CEQ") define terms in NEPA and detail agency responsibilities under the Act. See Marsh v. Oregon Natural Res. Council, 490 U.S. 360, 372 (1989) (CEQ regulations, which are entitled to substantial deference, impose a duty on all federal agencies). Under applicable CEQ regulations, a "[m]ajor Federal action" includes actions with "effects that may be major and which are potentially subject to Federal control and responsibility." 40 C.F.R. $\S 1508.18$ (2003). "Federal actions" tend to include "specific projects, such as construction or management activities located in a defined geographic area." Id.

Although there is "[n]o litmus test" for determining whether an action is a "major Federal action," Save Barton Creek Ass'n v. Fed. Highway Admin., 950 F.2d 1129, 1134 (5th Cir. 1992), a court may consider the following factors: (1) whether the project is federal or non-federal; 
(2) whether the project receives significant federal funding; and (3) when the project is undertaken by a non-federal actor, whether the federal agency must undertake "affirmative conduct" before the non-federal actor may act, Mineral Policy Center, 292 F. Supp. 2d at 54-55 (citing generally Macht v. Skinner, 916 F.2d 13 (D.C. Cir. 1990)). NAWS was authorized by federal statute and, although it involves both federal and state participation, BOR is charged with the planning and construction of the project. In addition, the federal government will provide $65 \%$ of the funding for the $\$ 145$ million project. That this is a "[m]ajor Federal action" cannot be seriously disputed.

The second threshold question is whether NAWS will "significantly affect[] the quality of the human environment ...." 42 U.S.C. $\S 4332(2)(C)$ (emphasis added). Although the statute is silent, CEQ regulations provide factors for determining whether an action is significant. ${ }^{12}$ Whether there may be a significant effect on the environment requires consideration of two factors, "context and intensity." 40 C.F.R. $\S 1508.27$. "Context simply delimits the scope of the agency's action, including the interests affected. Intensity relates to the degree to which agency action affects the locale and interests identified in the context part of the inquiry." Nat'l Parks \& Conservation Ass'n v. Babbitt, 241 F.3d 722, 731 (9th Cir. 2001). ${ }^{13}$

${ }^{12}$ Although there is regulatory guidance, courts have found that "[t]he statutory concept of 'significant' impact has no determinate meaning." River Road Alliance, Inc. v. Corps of Engineers, 764 F.2d 445, 449 (7th Cir. 1985). "Courts, no less than the agencies themselves, have found it trying to imbue this 'vague and amorphous term,' with a consistent and coherent definition." Public Citizen v. Nat'l Highway Traffic Safety Admin., 848 F.2d 256, 266 (D.C. Cir. 1988) (citing Hanly v. Kleindienst, 471 F.2d 823, 831 (2d Cir.1972)).

${ }_{13}$ The CEQ regulation, 40 C.F.R. $\S 1508.27$, defines these terms further:

(a) Context. This means that the significance of an action must be analyzed in several contexts such as society as a whole (human, national), the affected region, the affected interests, and the locality. Significance varies with the setting of the proposed action. For instance, in the case of a site-specific action, significance 
"[W]hether a particular agency action will have a 'significant' effect on the

environment is a substantive question left to the informed discretion of the agency proposing the action." Hoffman, 132 F.3d at 14. A reviewing tribunal must determine "whether the agency considered the relevant factors in a rational way." Public Citizen v. Nat'l Highway Traffic Safety Admin., 848 F.2d 256, 266 (D.C. Cir. 1988) (citing Hanly v. Kleindienst, 471 F.2d 823, 831 (2d

would usually depend upon the effects in the locale rather than in the world as a whole. Both short- and long-term effects are relevant.

(b) Intensity. This refers to the severity of impact. Responsible officials must bear in mind that more than one agency may make decisions about partial aspects of a major action. The following should be considered in evaluating intensity:

(2) The degree to which the proposed action affects public health or safety.

(4) The degree to which the effects on the quality of the human environment are likely to be highly controversial.

(5) The degree to which the possible effects on the human environment are highly uncertain or involve unique or unknown risks.

(6) The degree to which the action may establish a precedent for future actions with significant effects or represents a decision in principle about a future consideration.

(7) Whether the action is related to other actions with individually insignificant but cumulatively significant impacts. Significance exists if it is reasonable to anticipate a cumulatively significant impact on the environment. Significance cannot be avoided by terming an action temporary or by breaking it down into small component parts.

(9) The degree to which the action may adversely affect an endangered or threatened species or its habitat that has been determined to be critical under the Endangered Species Act of 1973. 
Cir.1972)). The D.C. Circuit has established four criteria for "assessing the adequacy of an environmental assessment's conclusion that there is no significant impact on the environment" and subsequent decision to forego preparation of an EIS. Watkins, 808 F. Supp. at $865 .{ }^{14}$

First, the agency [must] accurately identif[y] the relevant environmental concern. Second, once the agency has identified the problem it must ... take[] a "hard look" at the problem in preparing the EA. Third, if a finding of no significant impact is made, the agency must ... make a convincing case for its finding. Last, if the agency does find an impact of true significance, preparation of an EIS can be avoided only if the agency finds that the changes or safeguards in the project sufficiently reduce the impact to a minimum.

Town of Cave Creek v. FAA, 325 F.3d 320, 327 (D.C. Cir. 2003) (quoting Grand Canyon Trust v. FAA, 290 F.3d 340-41 (D.C. Cir. 2002)); see Maryland-Nat'l Capital Park and Planning Comm'n v. USPS, 487 F.2d 1029, 1040 (D.C. Cir. 1973) (similar). ${ }^{15}$

\section{Development of NAWS}

The determination regarding whether BOR "identified the relevant areas of environmental concern" and took a "hard look" at the problem is informed by a discussion of the

${ }^{14}$ The NEPA Revised Implementing Procedures state that "[p]roposed initiation of construction of a project or a major unit thereof" by BOR normally requires preparation of an EIS. National Environmental Policy Act Revised Implementing Procedures, 65 Fed. Reg. 52212, $\S 14.4$ (August 28, 2000).

15 The Court must examine the EA to "'ensure that the statement contains sufficient discussion of the relevant issues and opposing viewpoints to enable the decisionmaker to take a 'hard look' at environmental factors, and to make a reasoned decision."' Tongass Conservation Soc. v. Cheney, 924 F.2d 1137, 1140 (D.C. Cir. 1991) (quoting Natural Resources Defense Council, Inc. v. Hodel, 865 F.2d 288, 294 (D.C. Cir. 1988)). See also Nat'l Comm. for the New River, Inc. v. FERC, 373 F.3d 1323, 1327 (D.C. Cir. 2004). Whether an agency has properly considered CEQ regulatory factors may be analyzed under the third-step of the "hard look" analysis. See Town of Cave Creek, 325 F.3d at 327-28 (examining regulatory factors, including those listed in 40 C.F.R. $\S 1508.27$, in determining whether the agency was able to make a convincing case for its finding). 
Boundary Waters Treaty and the extensive international negotiation, cooperation and study that has permeated the development of NAWS as a result of the United States's treaty obligations.

In 1909 the governments of the United States and Great Britain executed the "Treaty Between the United States and Great Britain Relating to Boundary Waters, and Questions Arising Between the United States and Canada" ("Boundary Waters Treaty" or “Treaty"). See 36 Stat. 2448 (Jan. 11, 1909). In relevant part, Article IV of the Treaty provides, "[i]t is further agreed that the waters herein defined as boundary waters and waters flowing across the boundary shall not be polluted on either side to the injury of health and property on the other.” 36 Stat. 2450.

The Boundary Waters Treaty contains mechanisms for resolving disputes arising from the use of boundary waters. Article VII of the Treaty establishes the International Joint Commission ("IJC"), and subsequent articles provide for both non-binding and binding dispute resolution. Under Article IX, the government of either the United States or Canada can refer to the IJC any "questions or matters of difference arising between them involving the rights, obligations, or interests of either in relation to the other." 36 Stat. 2452. With respect to these referred matters, the IJC is empowered to generate non-binding reports containing "conclusions and recommendations as may be appropriate." Id. The IJC can issue binding decisions on referred matters under Article X of the Treaty only if both parties consent. 36 Stat. 2453. The binding dispute resolution procedures have never been invoked.

In 1965, Congress first authorized the construction of the Garrison Diversion Unit Project ("GDU") in North Dakota. See Act of August 5, 1965, Pub. L. No.89-108, 79 Stat. 433; Nat'l Audubon Soc'y v. Watt, 678 F.2d 299, 302 (D.C. Cir. 1982). In light of the GDU project, 
the two neighboring countries sought a recommendation from the IJC pursuant to the Boundary Waters Treaty. "The IJC in 1977 recommended against any Garrison Diversion construction which could affect waters flowing into Canada unless Canada and the United States agree that the risk to Canada is eliminated or of no concern." AR at 7806, Comments from the Canadian Section of the Canada-U.S. Garrison Consultative Group, July 9, 1999 (emphasis in original). The United States and Canada established the Garrison U.S./Canada Consultative Group in 1981 as a venue for ongoing discussions. ${ }^{16}$

After passage of the GDU Reformulation Act in 1986, the planning and development of the current NAWS project began. AR at $8309 .{ }^{17}$ In 1993, the State of North Dakota, which sponsors the NAWS project with the Bureau, requested review of NAWS by the Joint Technical Committee (“JTC"), composed of U.S. and Canadian experts, which had been set up by the Garrison Consultative Group. AR at 8309. Among other studies, the JTC appointed an Engineering-Biology Task Group ("Task Group”), with members from both countries, to review the project. AR at 8309. The Task Group issued its report in May 1994, finding, inter alia:

- $\quad$ "A number of pathways exist by which biota transfer has occurred, may be occurring, or could occur even without the completion of NAWS," such as

16 The Garrison Consultative Group had federal agency representatives from the U.S. and Canada, North Dakota and Manitoba representatives, under co-chairs from the U.S. State Department and Canadian Foreign Affairs. AR at 8311.

17 The GDU, as originally designed, was never completed. In 1986, Congress passed a reformulation of the GDU, the Garrison Diversion Reformulation Act, Pub. L. No. 99-294 ("GDRA"). NAWS was authorized pursuant to the GDRA, as amended by the Dakota Water Resources Act of 2000, Pub. L. No. 106-554, App. D. Title IV ("DWRA"), reprinted in 114 Stat. 2763A-282. The DWRA requires that, prior to construction on NAWS, "the Secretary [of the Interior], in consultation with the Secretary of State and the Administrator of the Environmental Protection Agency, must determine that adequate treatment can be provided to meet the requirements of the [Boundary Waters Treaty]." Id. 
fisheries management, bait buckets, boat bilges and boat hulls;

- "The most acceptable method of fully overcoming [the transfer of non-native biota into the Hudson Bay drainage] would be to treat the water to acceptable drinking water standards prior to its transport into the Hudson Bay drainage;"

- $\quad$ "[A]ll pipeline options had a relatively low risk of transferring biota to the Hudson Bay drainage if they included chloramination at the source . . . to control slime growth."

- $\quad$ "Because of the consequences of a pipeline failure, operations, maintenance, and replacement must ensure the integrity of the pipeline for its entire operational life;" and

- "If chloramination with the Missouri River drainage proves to be effective in addressing biota transfer concerns, standard engineering practices for construction, maintenance, and replacement could be followed."

AR at 1203-05. Further, the Task Group report stated that if the water were disinfected to drinking water standards, "there would be no concerns regarding leaking, pipeline rupture" or other piping incidents. AR 1220. The water could be "considered adequately treated for the purposes of mitigating biota transfer," "[i]f actual pilot studies demonstrate that Giardia and viruses can be inactivated to levels required for drinking water (i.e. 3 log inactivation for Giardia and $4 \log$ inactivation for viruses) at the Continental Divide...." AR at 1220. This report represented a welcome concurrence of opinion between representatives for both countries and has been highly relied upon by U.S. planners ever since.

In 1993-94, Cryptosporidium was found in municipal water supplies in Detroit. "All hell [broke] loose in the world of water treatment." AR at 8309. Thereafter, from 1994 to 1999, the U.S. and Canada sections of the JTC "argue[d] (but politely) about [the] implications of finding Cryptosporidium in Detroit and what the [Consultative Group] really meant when they accepted the findings of the ... Task Group with regard to disinfection vs. removal of biota." AR 
at 8310 . The problem identified was that Cryptosporidium is not amenable to treatment with chloramination; a problem the Task Group had not foreseen when it made its recommendation.

In December 1994, the consulting engineers for NAWS completed the "Pre-Final Design" for the project. AR at 1246-61. This document stated that two alternative WTP locations were evaluated to address biota transfer concerns. "The locations included siting the treatment plant in the Missouri River Basin, and siting upgrades and treatment plant expansions at the Minot WTP. The recommended plan involves upgrading and increasing the capacity of the Minot WTP." AR at 1256. The basis for this critical recommendation -- full water treatment in Minot, rather than in the Missouri River Basin prior to crossing the divide -- is not revealed in the administrative record before the Court.

However, as a result of the biota transfer concerns expressed by the Task Group, the consulting engineers on the NAWS project conducted a Chloramine Challenge Study in 1995 that was "a scientific evaluation to document the efficiency and applicability of both chloramination and ozonation in meeting . . . biota transfer concerns." AR at 1263 . The study focused on the use of chloramines and ozone for disinfection of Lake Audubon water to meet the 1989 Surface Water Treatment Rule (“SWTR”) "requirements, i.e., 3-log (99.9\%) inactivation of Giardia cysts and at least 4- $\log (99.99 \%)$ inactivation of viruses.” AR at 1270. "This study demonstrated that chloramines could be employed for disinfection of Lake Audubon water." AR at 1318. Nonetheless, the engineers advised that "the primary method of biota control for the NAWS project is the total containment of all Missouri River water within the pipeline system from the intake in the Missouri River Basin to the Minot Water Treatment Plant in the Hudson Bay Basin. Disinfection of the water supply provides an additional level of risk reduction to the 
already low risk provided by the pipe containment system." AR at 7710, Consultant Letter to State Water Commission, June 6, 1999.

The Garrison Consultative Group and the Joint Technical Committee met together in Washington, D.C. on July 9, 1999. Canada's representatives continued to urge full water treatment at the source for Missouri River water, rather than piping to Minot before full treatment. While recognizing that the Task Group had agreed to the earlier drinking water standards for treatment at the source, the Canadians argued that these standards were routinely updated and, in fact, had been updated since 1994. Since "only highly performing filtration systems were successful in treating water containing some protozoans such as Cryptosporidium," Canada contended that reliance on chloramination alone was no longer reasonable. AR at 7807 ("It is not reasonable that the NAWS project would be built to an outdated standard and then would not be upgraded at any time in the future as additional scientific information emerges."). Fundamentally, Canada argued that "it is almost certain that failure will occur [during the lifetime of the project] with the potential for enormous consequences for Canada. While the project benefits accrue to the United States, the enormous risks are externalized to Canada." AR at $7810 .^{18}$

18 A memo apparently prepared for a meeting of the U.S. Section of the Consultative Group meeting in August 1999 made the same point:

While the United States might conclude that the benefits outweigh the losses [of biota transfer] (potential only), Canada may not have any benefits that could outweigh any potential losses so they may have nothing to lose by being very conservative. If the roles were reversed, the positions of the two countries might also be reversed.

AR at 7845, Fish Pathogen Risks at the Garrison Diversion Project, Undated. 
Canada's position caused some concern on the U.S. side of the border. The U.S. Section of the Consultative Group, comprised of representatives from the Department of State, EPA, North Dakota, BOR, and the Fish and Wildlife Service (another agency within the Department of the Interior), debated what to do in light of Canada's opposition. North Dakota was "[r]eady to move forward" and to schedule bids. AR at 7832, Handwritten Notes from meeting of U.S. Section of Consultative Group, July 16, 1999. The Bureau wanted to know "[d]o we really have a project" and "[w]hat about filtration before the divide." AR at 7832 . The problem with filtration at the Missouri River before the divide was its cost of " $\$ 30 \mathrm{M}$. beyond current plan," which would be funded by the federal government. AR at 7833 . The meeting participants also discussed "[n]ew information" concerning viruses, zebra mussels, and $\mathrm{WD},{ }^{19}$ as well as the fact that ozone had been dropped in favor of chloramination for disinfection at the source. AR at 7834. It was noted that chloramine disinfection at the Missouri River "[c]an't remove organics." AR at 7834. When discussing "Risk Balancing," one of the participants appears to have commented that it is "[n]ot reasonable for US to provide a risk free project." AR at 7833 .

The three federal agencies (EPA, State and DOI) met with the U.S. Section of the Consultative Group in Denver on August 11, 1999, and agreed that they needed additional information to assess "the relative risk for biota transfer." AR at 7920. This study would "examine incremental risks over and above the existing nature and human pathways" by which Missouri River Basin biota might reach the Hudson Bay Basin. AR at 8123, Email, BOR

19 WD (Myxobolus cerebralis) was "found in [the] upper reaches of Missouri River [in 1999]. For a second time in this century, all hell [broke] loose in the water treatment world." AR at 8309, Project Overview, Undated. 
Regional Director Maryanne Bach to Richard Kellow, Environment Canada, October 29, 1999. The study would "not include any analysis of consequence" if a release of foreign biota were to occur in the Hudson Bay Basin. AR at 8123; see also AR at 8627, Email re NAWS $\mathrm{C}$ [omparative] $\mathrm{R}$ [isk] $\mathrm{A}$ [ssessment] WkGp ("“[W]e are not viewing the study as a true comparative risk analysis since [the] consequence of transfer is not addressed. Rather, we are viewing the study as an interbasin biota transfer likelihood comparison.")

The CRA identified existing causes of biota transfer between the Missouri River Basin and the Hudson Bay Basin, including pipeline connections, bait buckets, live wells, boats, trailers, and tackle; authorized fish stocking programs; and birds. At the end of the study, it was concluded that the "CRA demonstrates that although NAWS might transfer low levels of biota not native to the [Hudson Bay Basin], these transfers would likely be very small fractions of transbasin transfers from non-project pathways.” AR at 8367, Draft Comparative Risk Analysis, March 2000. In other words, the CRA concluded that fishermen and birds would transfer more non-native biota between the Basins than three and one-half billion gallons of water each year.

EPA was not impressed with the draft CRA due to "some of the approaches and a general lack of documentation on many of the assumptions that went into the modeling." AR at 8583, Email from Assoc. Director, National Center for Environmental Assessment, EPA Headquarters, to John Giedt, EPA, April 19, 2000. EPA concluded that the draft CRA was not "at this stage a credible assessment." AR at 8583. In an internal EPA memo reviewing the draft CRA, later sent to BOR (AR at 8858-62), one EPA scientist discussed the lack of data to support the CRA's assumption that all WD spores sink, unlike Giardia or Cryptosporidium, which are also protozoans and float. 
Unless WD has developed some evolutionary expression of its DNA that directs its cellular machinery to increase its density (no data to support this), or some other biological mechanism it would be expected to behave similar to other protozoans and stay afloat . . . . It can also be assumed that WD has adapted itself quite well to being released in the water until it runs into something by virtue of it staying viable for up to 30 years. This could allow WD spores to float hundreds of miles downstream until they run into something. . . .

The [WD] spores may be concentrating in the reservoir from upstream sources, and the NAWS project may transport spores hundreds of miles into the Hudson Bay watershed where the chances of running into a Salmonid population may increase.

AR at 8849, Memo (EPA) Review of Draft Comparative Risk Analysis for NAWS, June 12, 2000. These comments were "much more technical" than BOR had expected and "would seem to require additional work." AR at 8863, Email (BOR), NAWS Comments. BOR was not exactly sure how to deal with the EPA comments "as EPA has made it clear that no matter what we do they won't accept the [C]RA." AR at 8863.

While BOR and EPA debated the credibility of the draft CRA, Defendant Maryanne Bach, the BOR Great Plains Regional Director, prepared an October 20, 2000, Briefing for the Secretary of the Interior. The Briefing noted the intense interest of North Dakota's Senators in NAWS and anticipated their urging the Secretary to make a decision on NAWS during his term in office, i.e., before a new President was inaugurated on January 20, 2001. Regional Director Bach predicted that approval of NAWS "would likely set a precedent in North Dakota for any other interbasin transfers into the Hudson Bay drainage of Canada." AR at 9157, Briefing for the Secretary, October 20, 2000. She suggested that "whatever level of treatment is deemed necessary for biota transfer control purposes will likely establish a 
benchmark for all other international (irrigation or M\&I) interbasin transfers." AR at 9157. She concluded that the "Boundary Waters Treaty has proven to be a major obstacle for the State of North Dakota to develop its water resources .... It is unlikely that Canada will formally endorse or otherwise accept any version of NAWS, regardless of the level of water treatment provided." Id. AR at 9157-58. The Briefing did not mention the ongoing discussion between BOR and EPA on the same topics.

A November 2, 2000 memo from Ms. Bach to the Commissioner of the BOR, forwarding the CRA, EA, draft FONSI, and a Biota Transfer Control Measures report, was designed "to initiate the formal consultation process within the respective agencies [DOI, EPA and State] relative to the" Boundary Waters Treaty. AR at 9166.

EPA prepared a draft Position Paper, dated December 12, 2000, for this formal consultation process. It reported that EPA had determined "that the proposed biota transfer controls do not adequately consider the potential for inter-basin transfer of disinfectant-resistant spore-forming protozoans (Cryptosporidium, Whirling Disease, or unknown fish pathogens)." AR at 9174, Draft EPA Position Paper, December 12, 2000. EPA advised that the "optimal method" to avoid transfer of invasive pathogens into the Hudson Bay Basin "is conventional treatment of raw water in compliance with all applicable EPA drinking water requirements, and additional post-filtered treatment ... prior to transport" across the divide. AR at 9175. Finally, EPA opined:

[T]he Minot water treatment plant can be used only with inclusion of the following conditions: pre-treatment of raw water prior to crossing the continental divide; appropriate engineering controls and fail-safe systems, including an appropriate number of automated pipeline isolation valves ...; adequate facility inspection, operations, maintenance, and 
capital replacement plans ...; conventional treatment of raw water in compliance with all applicable EPA drinking water requirements, and additional post-filtered treatment with ultraviolet (UV).

AR at 9175.

On January 18, 2001, the DOI Assistant Secretary of Water and Science

forwarded a Decision Document to officials at the Department of State and EPA stating that DOI had reached a conclusion regarding NAWS. See AR 9182-96, Memo, DOI Office of Ass't Sec., Water and Science, to Dir., Office of Canadian Affairs, State, January 18, 2001. NAWS would be approved by DOI with the following "guiding princip[les]":

1. "Appropriate biota transfer controls should be in place to minimize the potential risk of known or unknown invasive pathogens entering the Hudson Bay basin;"

2. "The project design should fully comply with the intent of the Boundary Waters Treaty of 1909, and meet the legal requirements of the Garrison Diversion Unit Reformulation Act of 1986;"

3. "The most cost-effective biota transfer control measures should be used;"

4. "The requirements for NAWS, a unique project, are specific to that project; the agencies will consider other projects on a case-by-case basis considering their unique qualities to ensure compliance with the Boundary Waters Treaty."

AR at 9193-94 (emphasis added). DOI told EPA that these guiding principles were intended to incorporate key language of EPA's position paper. AR at 9185. It was later determined by the U.S. Section of the Garrison Consultative Group that the pre-existing design and operations plan for NAWS met the guiding principles without significant adjustment. AR 9258-9260, Meeting Minutes, January 20, 2001; AR 9261, Draft Meeting Summary, March 20, 2001.

Thereafter, Secretary Bruce Babbit was informed that the "agencies support the need for the water supply project" and he signed the Decision Document on January 19, 2001, 
finding that NAWS would be compliant with the Boundary Waters Treaty. AR 9197 - 9200, at 9198, Secretarial Approval, January 19, 2001.

\section{Identifying Areas of Environmental Concern}

As documented in the preceding section, the issue of interbasin biota transfer generally has been the subject of considerable study and negotiation. Indeed, through various government and private studies, and with the participation of various bodies, including BOR, the Consultative Group, and EPA, areas of environmental concern have been identified, including the potential for transfer of treatment-resistant biota through NAWS.

As early as 1994, environmental agencies had become aware of treatmentresistant biota such as Cryptosporidium and the potential hazards they posed. International working groups such as the JTC examined and debated the implications of Cryptosporidium for the treatment or disinfection considerations in NAWS. EPA, BOR, North Dakota, and other agencies and federal departments discussed new information regarding viruses, WD, and zebra mussel, as well as the ineffectiveness of chloramine at disinfecting certain types of biota in Missouri River water. Indeed, EPA declared that NAWS did not adequately consider the potential for interbasin transfer of disinfectant-resistant, spore-forming protozoans such as Cryptosporidium, WD, or other unknown fish pathogens, and suggested more intensive treatment prior to transport across the divide. The record is clear; BOR was aware of treatment-resistant biota, the potential for ill-effect, and the shortcomings of existing NAWS treatment options.

\section{Taking a Hard Look}

That these issues were identified does not mean that the Bureau took a "hard look" at the problem. Federal Defendants argue that BOR considered how to best treat raw water 
for biota control through the 1995 Chloramine Challenge Study, the 1998 Biota Transfer Control Measures Report, and the CRA. ${ }^{20}$ However, these studies are fatally flawed because they rely in large part upon water treatment standards that are too narrow to satisfy the agency's NEPA obligation to examine the potential for significant effect on the quality of the human environment. Federal Defendants and North Dakota urge that the use of older water-treatment standards, including 1994 EPA regulations, does not violate NEPA and that "[t]here are no regulations, from the EPA or any other federal agency, that govern the disinfection of water for purposes of controlling the inter-basin transfer of foreign biota." Fed. Defs' Opp. and Motion for Summary Judgment at 20; see also North Dakota's Opp. and Motion for Summary Judgment at 9. While true, these points miss the mark. That use of 1994 EPA regulations does not violate NEPA -- nor, for that matter, treaty obligations -- is not determinative of an agency's obligations. Further, that there are no standards for governing disinfection in interbasin transfers does not, ipso facto, permit the agency to ignore a known potential for the transfer of foreign biota. Instead, the relevant inquiry is whether the agency had notice of a condition that could have a significant effect on the quality of the human environment. Such notice would rightfully be informed by both existing and older regulations. Claimed reliance upon studies that fail to consider current environmental concerns and standards is, therefore, not persuasive evidence that the agency took a hard look at the problem.

Federal Defendants point to the CRA's examination of WD as a representative of

20 The 1995 Chloramine Challenge Study and the 1998 Biota Transfer Control Measures Report considered pre-treating the raw water with ozone rather than chloramine, because chlorine is ineffective in controlling organisms like Cryptosporidium. See AR at 766-769. Ultimately, however, ozone was dropped from consideration because of potential ozone byproduct formation. AR at 1900 . 
more difficult-to-treat pathogens like Cryptosporidium, and suggest that this satisfied its NEPA obligations. ${ }^{21}$ It proudly concludes that the "treatment process is expected to result in a 99.9 to 99.99\% deactivation of such organisms by the time the water leaves the Minot plant." Fed. Defs' Opp. and Motion for Summary Judgment at 19.

The problem with this argument is, of course, that it ignores the issue here. The question is not the condition of the Missouri River water after full treatment, including UV treatment at Minot. The issue is whether the agency has considered the ramifications of piping water from the Missouri River, across the divide, to the Minot WTP with only chloramination at the source, despite the recognized fact that chloramination is not effective against Cryptosporidium, WD, or similar pathogens. ${ }^{22}$

BOR and North Dakota are joint proponents of the NAWS project. Years ago, in a document totally lacking in analysis, North Dakota rejected treatment of the water at the

${ }^{21}$ The Court does not select between contesting experts in commenting on the alleged flaws in the CRA. Nevertheless, it is acknowledged that the CRA was not viewed as a true comparative risk analysis because the consequences of transfer were not addressed. Furthermore, given the harsh analysis of its shortcomings by EPA, the analysis of WD in the CRA can hardly be considered a thorough and earnest analysis of the problems presented by the transfer of treatment-resistant biota.

22 Federal Defendants argue that interbasin biota transfer has already occurred and will continue to occur whether or not the NAWS project is completed. As an initial matter, the Court has serious doubts that the "transport by birds, fish-stocking programs, live bait transport, and through the transport of recreational or commercial watercraft" will transfer more non-native biota than 3.6 billion gallons of water every year. Fed. Def's Opp. and Motion for Summary Judgment at 13. Regardless, whether biota may be transferred by other means is only relevant if it can be shown that, absent NAWS, the transfer of foreign biota is likely to occur with environmental effects of similar intensity. Federal Defendants have made no showing that this is the case. Therefore, this point, while of possible relevance, does nothing to deter a finding that a massive water transfer program may independently have a significant effect on the quality of the human environment. 
Missouri River source, preferring to maintain the water treatment plant in Minot. See AR at 1256 (mentioning the possibility of siting a WTP in the Missouri basin, but stating simply that "[t]he recommended plan involves upgrading and increasing the capacity of the Minot WTP."). That decision has never been seriously re-visited. Instead, BOR and North Dakota have dedicated themselves to reducing the likelihood of pipeline releases and have refused -- despite EPA's warnings, despite Canada's position, despite Manitoba's TetrES report, and, most critically, despite acknowledging that chloramination will not prevent Cryptosporidium, WD, and other pathogens from crossing the divide -- to change their position. Whether this is the wisest action is not for litigation to decide. What has resulted from this obduracy, however, is a twofold problem: there has been no study of the consequences of leakage from the pipeline (whether slow leakage from the joints or a major break) and, therefore, no evaluation of the consequences of failure compared to more complete treatment at the source. ${ }^{23}$

As described above, throughout the international discussions and consultations that preceded the Final EA, Canada had been urging full treatment of Missouri River water to drinking water standards at the intake because it provided the best protection against introducing non-native biota into the Hudson Bay Basin. BOR did not fully analyze this option in the draft or

${ }^{23}$ The focus was instead placed on "total containment of all Missouri River water within the pipeline from the intake in the Missouri River Basin to the Minot Water Treatment Plant in the Hudson Bay Basin.” AR 7710, Consultant Letter to State Water Commission, June 6, 1999. Absent a major pipeline disaster, the amount of water that will be lost during the transfer across the basin divide is no doubt minor relative to the gross amount transferred. But, "total containment" is unlikely. The TetrES Report opines that "[i]t is not unusual that water systems leak, in fact, the best water systems have unaccounted-for-water of at least $5 \% \ldots$. [others] 10 $20 \%$." AR at 9836 . Reliance on these figures is not necessary to carry the point that some consideration of the amount and likelihood of leakage together with a thorough examination of the risks posed by treatment-resistant biota would appear critical to the agency's "hard look" at the interbasin biota transfer problem. 
Final EA; rather an economic justification for exclusion was included:

[T] he estimated cost of the expansion and upgrade of the Minot water treatment plant is approximately $\$ 15.9$ million. With full treatment within the Missouri River basin, not only would the pipeline have to be built before water could be sold, but a treatment plant would also have to be constructed, thereby increasing the up-front cost by $\$ 28$ million, which is an increase of approximately 60 percent. The entire cost of the treatment plant would have to be financed as part of the first phase, which would place a significant financial burden on the uses of project water and would therefore be cost prohibitive.

Minot has expressed the desire to maintain operation of its water treatment plant for economic expansion possibilities. In its current configuration, the Minot water treatment plant would be able to treat Missouri River water with few modifications. ... Construction of a new water treatment plant at the intake would initially result in the closure of the Minot water treatment plant (loss of existing invested capital). The construction of a treatment plant at the intake location would also involve additional issues with providing operations and maintenance of the facilities. The treatment plant at the intake would be in a remote location which would result in significant problems for O\&M [Operation and Maintenance] crews with regard to travel time to the location and ability to respond to O\&M problems on short notice. Construction of a new treatment plant at the intake site would be redundant with the capabilities that exist or will be added to the Minot plant. Other less expensive alternatives to achieve biota control are considered in more detail in later [sic] in this document. The use of Minot's water treatment plant for final treatment was considered the most viable and most supportable treatment alternative in terms of costs, financing, and use of existing facilities.

AR 0509-510. Thus, the Final EA determined that full treatment of water at the intake site

"would have required the construction of a complete, new treatment plant .... The total project cost (including 30 percent for contingencies, engineering, and administration) would be $\$ 28.2$

million." AR at 508-09. "The difference in cost between a full treatment plant at Lakes

Audubon or Sakakawea and upgrade of the Minot treatment plant is $\$ 12.3$ million.” AR at 509 .

For these economic reasons, full treatment of the water at the source was discarded from further 
consideration.

NEPA “operates to prevent a federal agency from taking any major action before that agency has considered the environmental effects of that action." Citizen Advocates for Responsible Expansion, Inc. v. Dole, 770 F.2d 423, 432 (5th Cir. 1985) (citing H.R. Conf. REP. No. 765, reprinted in 1969 U.S.C.C.A.N. 2751, 2756, 2757 \& 2771)); see Robertson, 490 U.S. at 369 (quoting 115 CONG. REC. 40425 (1969) (remarks of Sen. Muskie)) (NEPA “bring[s] pressure to bear on agencies "to respond to the needs of environmental quality."'). A court should intervene if it "becomes aware, especially from a combination of danger signals, that the agency has not really taken a "hard look" at the salient problems, and has not genuinely engaged in reasoned decision-making." Greater Boston Television Corp. v. FCC, 444 F.2d 841, 851 (D.C. Cir. 1970).

Federal Defendants argue that the risks of leakage are low and, therefore, that no further study is necessary. ${ }^{24}$ They repeatedly provide varied estimates that more than ninety-nine percent of biota will be disinfected under NAWS. While facially compelling, the argument ignores the fact that certain biota have been identified that may be impervious or highly-resistant

${ }^{24}$ Even if a federal action may have significant environmental effects, an agency may adopt mitigation measures that substantially or totally eliminate these effects and avoid preparation of an EIS. Maryland-Nat'l Capital Park \& Planning Commission, 487 F.2d at 1040. NAWS "incorporate[s] a number of conservative design features into the project," including pretreatment of the water at the source, isolation valves in the pipeline, and sophisticated monitoring equipment to detect leaks and pipeline failures. Fed. Def's Opp. and Motion for Summary Judgment at 15-16. However, a mitigated FONSI fulfills NEPA's requirements when it "completely compensate[s] for any possible adverse environmental impacts stemming from the original proposal" or reduces the possibility to a minimum. Cabinet Mountains Wilderness, 685 F.2d at 682. Absent some measurement of the quantum and intensity of any ecological effects from the release of even a small amount of treatment-resistant biota, which can be expected in even the most sophisticated pipeline systems, it cannot be said that risk of environmental impacts is reduced to a minimum. 
to the planned treatment measures. Therefore, even a low risk of leakage may be offset by the possibility of catastrophic consequences should any leakage occur. ${ }^{25}$ Without some reasonable attempt to measure these consequences instead of bypassing the issue out of indifference, fatigue, or through administrative legerdemain, the Court cannot conclude that BOR took a hard look at the problem.

\section{REMEDY}

Manitoba seeks a declaratory judgment and injunction requiring Federal Defendants to prepare, circulate for comment, and consider in decision-making an EIS relating to the project. In addition, Manitoba seeks a permanent injunction prohibiting Federal Defendants from authorizing or expending federal funds on the project, or taking further steps relating to the project until they comply with the requirements of NEPA.

The Court will remand this issue for completion of a more searching EA that considers an integrated analysis of the possibility of leakage and the potential consequences of the failure to fully treat the Missouri River water at its source given the agency's awareness of treatment-resistant biota. Asphalt Roofing Mfr's Ass'n v. ICC, 567 F.2d 994, 1006 (D.C. Cir. 1977) (remand to agency to determine the impact of actions on the quality of the human environment); see Hoffman, 132 F.3d at 18 ("because the question of whether the project may have significant adverse impacts is one that the [agency] must decide," the appropriate remedy is

25 The Court agrees with Manitoba that "even small percentage differences in effectiveness in reducing biota transfer [may involve] large differences in terms of the total number of organisms that might be transferred." Pltf's Reply at 19. Under the Preferred Alternative, as many as 3.6 billion treatment-resistant organisms may cross the basin divide each year, which translates into ten million organisms per day. Id. What may seem minor in terms of percentages may be substantial in net effect. 
to remand to correct the deficiencies in the record and analysis). Federal agencies must comply with the procedural requirements of NEPA and reach reasoned decisions on issues of environmental concern. Because disclosure of information critical to decision-making is a primary function of NEPA, an agency cannot be allowed to avoid producing a thorough EIS by ignoring a possible, but unexplored, environmental issue in the EA. Foundation on Economic Trends v. Heckler, 756 F.2d 143, 154 (D.C. Cir. 1985) (“An environmental assessment that fails to address a significant environmental concern can hardly be deemed adequate for a reasoned determination that an EIS is not appropriate."). In this case, the failure to take a hard look at the issue of treatment-resistant biota is a significant infirmity in the EA. BOR must evaluate seriously the risk that treatment-resistant organisms will create an "ecological disruption;" merely “[i]gnoring possible environmental consequences will not suffice." Heckler, 756 F.2d at 154. After doing so, it should reconsider its finding of no significant impact in light of this evaluation. Id.

Until BOR has completed a more thorough EA, the question of whether an EIS is required remains open and the Court will not grant the request for declaratory and injunctive relief requiring production of an EIS. The decision to issue an EIS is committed to the agency's discretion and any judicial review of a substantive finding of no significant impact is deferential. Baltimore Gas \& Elec. Co. v. Natural Res. Def. Council, 462 U.S. 87, 103 (1983) (a court should be "at its most deferential" when reviewing determinations that fall within an agency's area of expertise); see also Motor Vehicle Mfr's. Ass'n of the United States v. State Farm Mut. Auto. Ins. Co., 463 U.S. 29, 43 (1983) (the court must "not substitute its judgment for that of the agency."). The Court has identified a preliminary deficiency in the agency's decision not to issue an EIS -- a 
limited finding that the agency has failed to take a "hard look." A determination of whether the agency's failure to issue an EIS is supportable would be premature.

Although it will not order production of an EIS, the Court notes that Manitoba has raised the specter of significant environmental consequences that deserve serious consideration. The recognition by all parties that the interbasin transfer of biota generally can have potentially devastating consequences weighs heavily in support of the view that an EIS should be completed. Accordingly, the Court would expect that any subsequent FONSI, that does not incorporate revised treatment procedures, would provide some reasoned finding that the introduction of foreign treatment-resistant biota will not have significant environmental consequences. Notably, it will not be sufficient for BOR to forego preparation of an EIS by merely stating that the environmental effects are unknown or unmeasurable because the "degree to which the possible effects on the human environment are highly uncertain or involve unique or unknown risks" is an enumerated factor in the significant impact determination. 40 C.F.R. $\S 1508.27(\mathrm{~b})(5)$; accord Maryland-Nat'l Capital Park \& Planning Commission, 487 F.2d at 1041 ("an inability to solve the problem would not justify failure to write a detailed impact statement concerning effect on environment").

The Court will defer ruling on Plaintiff's request for an injunction prohibiting Federal Defendants from authorizing or expending federal funds on the project or taking further steps relating to the project. Where NEPA violations are determined in connection with an ongoing project, courts must decide whether the project should be halted pending completion of an EIS. Natural Res. Defense Council, Inc. v. U.S. Nuclear Regulatory Comm'n, 606 F.2d 1261, 1273 (D.C. Cir. 1979); see Sierra Club v. United States Army Corps of Engineers, 701 F.2d 
1011, 1030-31 (2d Cir. 1983) (where an agency has failed to take a hard look at the environmental consequences of a project, a court may enjoin it from pursuing the project until an EIS is prepared). ${ }^{26}$ What is called for is "a 'particularized analysis' of the violations that have occurred, of the possibilities for relief, and of any countervailing considerations of public interest." Alaska v. Andrus, 580 F.2d 465, 485 (D.C. Cir. 1978), vacated in part on other grounds, 439 U.S. 922 (1978) (quoting Jones v. District of Columbia Redevelopment Land Agency, 499 F.2d 502, 513 (1974)). In making this determination, a court should consider the rationale for injunctions, including the need to prevent "irreversible effect on the environment, until the possible adverse consequences are known," and the need to "preserve for the agency the widest freedom of choice when it reconsiders its action after coming into compliance with NEPA." Realty Income Trust v. Eckerd, 564 F.2d 447, 456 (D.C. Cir. 1977).

The Court is acutely aware that NAWS would provide high-quality water to parts of North Dakota that have a long history of water-supply problems. The Court is also mindful that there are weighty outstanding questions regarding the possible environmental impact of this project. The paucity of current information regarding the status of construction, and the brevity of legal argument devoted to the injunction question, inhibit the Court's ability to engage in a particularized analysis of the need for an injunction. Accordingly, the Court will defer ruling on Manitoba's request. A status hearing will be set at which the parties will advise the Court on the status of NAWS construction and propose briefing or further argument on this remaining issue.

${ }^{26}$ Under this circuit's long-standing test, an injunction should issue upon the court's consideration of: (1) the plaintiff's likelihood of prevailing on the merits; (2) the threat of irreparable injury to the plaintiff in the absence of injunctive relief; (3) the possibility of substantial harm to other interested parties from the injunctive relief; and (4) the interests of the public. WMATC v. Holiday Tours, 559 F.2d 841, 842- 43 (D.C. Cir.1977). 


\section{CONCLUSION}

For the reasons stated, Plaintiff's motion for summary judgment is GRANTED

IN PART and DENIED IN PART. Federal Defendants' and Intervenor-Defendant's motions for summary judgment are DENIED. The Court will retain jurisdiction over this matter. A separate Order accompanies this Memorandum Opinion.

DATE: February 3, 2005.

$/ \mathrm{s} /$

ROSEMARY M. COLLYER

United States District Judge 